\title{
Analisis Pemikiran Pendidikan Menurut Ibnu Sina dan Kontribusinya Bagi Pendidikan Islam di Era Modern
}

\author{
Siti Qurrotul A'yuni \\ UIN Sunan Kalijaga Yogyakarta
}

\begin{abstract}
Keywords:
Educational Thinking, Ibnu

Sina, Islamic Education,

Modern
\end{abstract}

Kata Kunci:

Analisis Pemikiran

Pendidikan, Ibnu Sina,

Pendidikan Islam, Era

Modern

\section{*Correspondence}

Address:

sitiqurrotulayuni95@gmail.com

\begin{abstract}
Education is an inexhaustible material for discussion. This is because education is continuous and dynamic. Critical thinking of classical educational figures is still worth discussing. Ibnu Sina (Avicenna) isa well-known Islamic philosopher in the field of medical science, however much of his thoughts are also contained in a lot of education and contribute to modern education today. The library research method used by the author in analyzing Ibnu Sina's educational thinking and its contributed to Islamic education in the modern area. Compiled from reference source obtained, Ibnu Sina's educational concept includes discussing the goals of Islamic education, the curriculum at the first level of educational units, how to be an educator, provisions to become a learner and blend whit the environment. The explanation in Ibnu Sina's thoughts is contained in this scientific article. The explanation in that thought can be a reference, even innovations in Islamic educator thought, as well as adding scientific insights about modern Islamic education today.
\end{abstract}

Abstrak: Pemikiran tokoh pendidikan klasik masih layak untuk dibahas karena terkadang melampaui zamannya dan dalam beberapa hal dianggap cocok dengan konteks pendidikan masa kini. Salah satu tokoh yang dimaksud adalah Ibnu Sina. Ibnu Sina (Avicenna) adalah seorang filsuf Islam ternama di bidang ilmu kedokteran, namun banyak pemikirannya juga membahas tentang pendidikan dan dianggap berkontribusi pada perkembangan pemikiran pendidikan modern. Tujuan penelitian ini adalah menganalisis pemikiran pendidikan Ibnu Sina dan kontribusinya pada pendidikan Islam di masa modern. Dihimpun dari berbagai sumber referensi yang diperoleh, konsep pendidikan Ibnu Sina antara lain membahas tentang tujuan pendidikan Islam, kurikulum pada satuan pendidikan tingkat pertama, bagaimana menjadi pendidik, bekal menjadi peserta didik dan lingkungan belajar. Pokok-pokok pemikiran tersebut dapat menjadi landasan bagi pengembangan pendidikan masa kini terutama sebagai landasan filosofis dalam merancang sistem pendidikan yang baik namun tetap adaptif.

\section{PENDAHULUAN}

Pendidikan merupakan usaha sadar yang dengan sengaja dirancang untuk mencapai tujuan yang telah ditetapkan. Pendidikan bertujuan untuk meningkatkan kualitas sumber daya manusia ialah melalui proses

${ }^{1}$ Jasmani Asf, Syaiful Mustofa, Supervisi Pendidikan: Terobosan Baru dalam Peningkatan Kinerja pembelajaran di sekolah. ${ }^{1}$ Pengertian ini yang saat ini tertanam di benak kita. Sehingga seseorang yang ingin mempelajari sesuatu harus berkumpul di sekolah. Berada dalam satu ruangan, duduk alam satu majelis, lalu terjadilah

Pengawasan Sekolah dan Guru (Jogjakarta: AR-RUZZ MEDIA, 2013), 15. 
interaksi antara pendidik dan peserta didik.

Lalu bagaimana Islam memandang pendidikan? dalam Islam ada beberapa sudut pandang yang berbeda terhadap pengertian tentang pendidikan. Salah satunya menurut pandangan cendekiawan muslim terdahulu, ia adalah Ibnu Sina. Dengan kecerdasan yang luar biasa banyak ilmu-ilmu yang dipelajarinya. Banyak pula karya-karya yang telah dituliskan. Khususnya dalam bidang pendidikan tertuang dalam kitab al-Siyasah fi alTarbiyah.

Salah satu isi yang dipaparkan dalam kitab tersebut adalah kewajiban orang tua dalam memberi nama yang baik kepada anaknya dan memilih perawat yang baik. $^{2}$ Memberi nama yang baik pada anak akan dibawanya sampai seumur hidup, begitupun memilih perawat. Jika dalam lingkungan keluarga seorang anak dididik dengan kebaikan, maka ia akan tumbuh dam memiliki kepribadian yang baik pula.

Pembahasan ini penulis anggap penting, karena sebagai calon pengelola pendidikan Islam, hendaknya mahasiswa Tarbiyah mengetahui terlebih dahulu hakikat pendidikan Islam menurut Pemikiran tokoh Muslim pendahulu. Sehingga diharapkan kedepannya para pengelola lembaga pendidikan Islam tidak keliru dalam mengambil tindakan terkait pendidikan di-era pesatnya digital saat ini.

\section{METODE PENELITIAN}

\section{Metode penelitian juga merupakan cara sistematis untuk}

\footnotetext{
2 Muhammad Nasher, al-Fikr al-Tarbawi al-'Arabi alIslami: al-juz'u al-Tsani min Qira'at fi al-Fikr alTarbawi (Kuwait:Wukalah al-Mathba'at, 1977), 284. Sebagaimana dikutip dalam buku karya Safrudin Aziz yang berjudul "Pemikiran Pendidikan Islam" (Yogyakarta: Kalimedia, 2015), 83.
}

menyusun suatu karya ilmiyah agar mencapai tujuan tertentu. ${ }^{3}$

Penyusunan artikel ilmiah ini menggunakan metode Penelitian Kepustakaan (Library Research), dimana penulis mencari data dari berbagai literasi di perpustakaan yang berhubungan dengan judul penelitian, baik melalui media cetak maupun digital.

Disebut penelitian kepustakaan sebab data-data atau bahan-bahan yang diperlukan dalam menyelesaikan penelitian yang dimaksud berasal dari perpustakan baik berupa buku, ensiklopedi, kamus, jurnal dokumen, majalah dan lainnya. ${ }^{4}$ Saat ini berkembangnya teknologi memudahkan peneliti mencari data berupa dokumen menggunakan media digital sebagai sumber penelitian.

\section{HASIL DAN PEMBAHASAN Biografi singkat Ibnu Sina}

Nama lengkap Ibnu Sina adalah Abu Ali Al-Husain ibn Abdullah ibn alHasan ibn Ali Ibn Sina al-Hakim. Ibnu Sina lahir pada tahun $370 \mathrm{H} / 980 \mathrm{M}^{5}$ Beliau dilahirkan di Khormeisan berdekatan dengan Bukhara dan berbangsa Balkha (ahli Balkha), sekarang Uzbekistan, ibu kota Samani, sebuah kota peninggalan dari dinasti Persia di Asia Tengah dan Khurasan. Ibunya bernama Satareh juga berasal dari Bukhara, dan ayahnya bernama Abdullah seorang penganut Ismailiyah yang disegani, dan merupakan ilmuwan dari Balkha, sebuah kota penting dari kekuasaan Samani yang sekarang merupakan

\footnotetext{
3 Sutrisno Hadi, Metodologi Riset, (Yogyakarta: Pustaka Pelajar, 2015). 4.

${ }_{4}$ Nursapia Harahap, Penelitian Kepustakaan, Jurnal Iqra' Volume 08 No.01 Mei, 2014. h. 16.

5 Abdurrahman Assegaf, Aliran Pemikiran Pendidkan Islam Hadhadarh Keilmuan Tokoh Klasik Sampai Modern, (Jakarta: Raja Grafindo, 2013). 77.
} 
bagian dari wilayah Afghanistan. ${ }^{6}$ Banyak literasi yang membahas tentang tokoh pemikir Islam ini dan diterjemahkan dalam berbagai bahasa. Baik berbentuk cetak atau digital. Tiap kali berbicara filsuf Muslim pendahulu, tentu tidak akan terlepas pembahaan tentangnya. Maka dari itu penulis membahas secara singkat sejarah hidup Ibu Sina atau dalam bahasa internasional dikenal dengan nama Avicenna.

Pendidikan yang ditempuh Ibnu Sina kebanyakan sama dengan yang lainnya, namun terdapat keistimewaan ketika kecil sudah terlihat kecerdasannya yang luar biasa bahkan sulit dicari tandingannya, dikatakan bahwa ia hafal al-Qur'an dalam usia di bawah 10 tahun. Dalam hal ini, Ahmad Fuad al- Ahwani mengatakan: "Pada usia 10 tahun ia telah menyelesaikan pelajaran Al-qur'an, sastra dan Bahasa Arab. Kemudian ia belajar ilmu fiqig pada seorang guru yang bernama Ismail yang terkenal sebagai sosok zuhud. Di samping itu, ia belajar metematika dan ilmu ukur pada 'Ali Abu 'Abdullah anNatili. kemudian setelah itu ia belajar sendiri dengan membaca berbagai buku, termasuk buku Syarh sehingga menguasi ilmu semantik. Tidak ketinggalan pula ia mempelajari buku Ocledeus menenai ilmu ukur (geometri) dan buku-buku lain tentang ilmu kedokteran. Dalam usia 18 tahun ia telah selesai mempelajari semua ilmu tersebut".?

Ibnu Sina kurang lebih meninggalkan 267 buku. Kebanyakan berbahasa Arab, selainnya berbahasa Persia. Karyanya yang terkenal antara lain: As-syifa', An Najah, al Isyarah wa at

\footnotetext{
${ }^{6}$ Alwizar, Pemikiran Pendidikan Ibnu Sina: an-Nida'. Jurnal Pendidikan Islam,Vol.40, No.1 Januari - Juni 2015. 12.
}

Tanbihat, al-Qanun fi at Thibb yang selama lima abad menjadi literatur penting bagi fakultas kedokteran di Eropa. Kecerdasan luar biasa yang dimilikinya membuatnya tak berhenti belajar, ia melanjutkan pengetahuannya tentang logika, matematika dan geometri, dengan belajar sendiri. tidak berapa lama setelah itu, ilmu-ilmu tersebut dapat dikuasainya. Kemudian ia mulai membaca semua buku yang ditulis untuk ilmu kedokteran. Tak lama berselang, lalu ia memiliki keduduka yang sama seperti seorang dokter. Rupanya kepandaian seorang dokter itu tidak menjadi tujuannya. Hingga pada saat usianya menginjak 18 tahun, ia berkata: "Kalau malam sudah datang, aku harus segera pulang ke rumah. Kuletakkan lampu di depanku, maka sibuklah aku membaca dan menulis. Jikalau kantuk menyerangku atau aku merasa cape, maka aku menoleh ke samping dan aku mnnum segelas anggur, agar kantuk hilang atau kekuatanku kembali. Kemudian kembalilah aku membaca. Demikianlah kerjaku tiada hentinya, sehingga aku dapat menguasai pelbagai ilmu pengetahuan. Segalailmu yang aku pelajari waktu itu, masih kuingat sekarang, ketika aku menulis sejarah hidup ini. Pada hari ini, tidak ada lagi ilmuku bertambah". ${ }^{8}$ Hal ini menjadi bukti bahwa Ibnu Sina merupakan sosok yang gemar belajar. Maka dari itu tidak heran jika sejarah mencatat namanya sebagai cendikiawan.

Pekerjaan pertamanya menjadi fisikawan untuk emir, yang diobatinya dari suatu penyakit berbahaya. Majikan Ibnu Sina memberinya hadiah atas hal tersebut dengan memberinya akses ke perpustakaan Raja Samanids,

\footnotetext{
7 Ahmad Fuad al- Ahwani, Filsafat Islam, cet. VIII. Jakarta: Pustaka Firdaus, 1997, 83.

8 Suwito dan Fauzan, Sejarah Pemikiran Para Tokoh Pendidikan. (Bandung: Angkasa, 2003), 111-112.
} 
pendukung pendidikan dan ilmu. Ketika perpustakaan kebakaran, musuhmusuh Ibnu Sina menuduh dialah orang yang membakarnya, dengan tujuan untuk menyembunyikan sumber pengetahuannya. ${ }^{9}$

Ibnu Sina wafat pada tahun 428 H/1037 M, tepatnya di Hamadan Iran, karena penyakit maag kronis. Ia wafat ketika sedang mengajar di sebuah sekolah. Saat itu dia sedang sakit parah, namun tetap bersikeras untuk mengajar anak-anak. Sehingga saat di larikan ke dokter nyawanya sudah tidak tertolong lagi. ${ }^{\mathbf{1 0}}$

\section{Pokok-Pokok Pemikiran Ibnu Sina Tentang Pendidikan}

Penjelasan sebelumnya telah dipaparkan sejarah singkat dari perjalanan hidup ibnu Sina. Saat ini akan dijabarkan mengenai pokok pemikiran Ibnu Sina tentang pendidikan.

Ibnu sina adalah tokoh filsuf muslim yang masyhur di telinga. Pemikiran-pemkirannya dapat dilihat dan ditemukan dari berbagai karya yang dibuatnya, dan telah di terjemahkan ke dalam berbagai bahasa. Nama Ibnu Sina semakin dikenal ketika ada orang lain yang membahas tentang pemikirannya. Salah satunya adalah Prof. Dr. Muhammad Athiyah Al Abrasy dengan judul Al-Tarbiyah Al-Islamiyah wa Falasifatuha, yang diterjemahkan ke dalam bahasa Indonesia menjadi "Pokok-Pokok Pikiran Ibnu Sina tentang Pendidikan" oleh Syamsuddin Asyrafi, Ahmad Warid Khan dan Nizar Ali, berikut beberapa poin pemikiran pendidikan menurut Ibnu Sina yang di paparkan sebagai berikut dibawah ini :11

\footnotetext{
9 Syamsul Kurniawan \& Erwin Mahrus, Jejak Pemikiran Tokoh Pendidikan Islam (Yogyakarta: Ar-Ruzz Media, 2011), 76-77. 10 Ibid, 77.
}

1. Kurikulum Tingkat Pertama dalam Pendidikan Islam

Ibnu Sina mempunyai pendapat yang cukup terkenal dalam bidang Pendidikan Anak. Pandangan beliau mengenai kurikulum tingkat pertama dalam pendidikan Islam dapat dikemukakan sebagai berikut: Pertamatama sebaiknya anak itu belajar Alqur'an, tentu saja ketika anak tersebut telah siap secara fisik dan mental untuk belajar. Pada waktu yang sama, ia seyogyanya juga belajar huruf abjad, diajarkan dasar-dasar pendidikan agamadan belajar syair dengan dimulai syair-syair sederhana agar mudah dihafal. Lalu syair-syair berisikan tentang budi pekerti, penghargaan tentang ilmu, celaan terhadap kebodohan, dorongan melakukan perbuatan baik, berbakti kepada orang tua dan lain sebagainya. ${ }^{\mathbf{2}}$

Dengan kata lain, pertama-tama sebaiknya seorang anak itu diberi pelajaran Al-Quran. Guru mengawalinya dengan membacakan surat-surat pendek, ayat demi ayat kemudian ditirukan anak-anak berulang kali hingga mereka hafal. Periode pertama seorang anak tentunya mereka belum bisa membaca,oleh karena itu guru yang mencontohkan, mentalkin anak supaya mereka bisa mengikuti ayat-ayat yang dibacakan gurunya.

Setelah itu, mereka juga belajar pelajaran lain seperti membaca dan menulis huruf hijaiyah, tanda baca seperti fathah/fathatain, kasrah/kasratain, dlommah/dlomatain. Latihan merangkai huruf menjadi kata dan kata menjadi kalimat. Setelah anak selesai menghafal surat-surat pendek Al-qur'an dan mengetahui dasar-dasar tata bahasa Arab secara sederhana,

\footnotetext{
11 Muhammad 'Athiyah Al-Abrasy, Pokok-Pokok Pikiran Ibnu Sina tentang Pendidikan, 1994. hlm 22.

12 Muhammad 'Athiyah Al-Abrasy, Pokok-Pokok Pikiran Ibnu Sina ... , 13.
} 
barulah kemudian diarahkan untuk mempelajari pelajaran lainnya sesuai dengan tingkat kesiapan dan kemampuannya.

2. Pendidikan Keterampilan sebagai Bekal Hidup

Menurut Ibnu Sina apabila anak telah selesai belajar Al-qur'an dan menguasai dasar-dasar tata bahasa Arab secara sederhana, kalau dipandang perlu, hendaknya diberi juga pelajaran keterampilan. Dengan catatan, guru harus menyadari betul bahwa tidak setiap pelajaran keterampilan itu cocok bagi setiap anak, namun harus disesuaikan dengan bakat dan minatnya. Sebagai contoh, kalau seorang anak senang keterampilan menulis, maka dalam pelajaran bahasa perlu ditambahkan materi pelajaran surat menyurat, masalah kehumasan, administrasi umum (administrasi perkantoran), keterampilan menulis halus, sebaliknya kalau dia menghendaki keterampilan lain yang sesuai dengan bakat dan minatnya, juga harus dilayani.

Bila materi-materi pendidikan dasar ini telah dapat diselesaikan dengan baik, selanjutnya yang perlu diperhatikan kembali adalah masalah bakat dan minat siswa tersebut. Jika minatnya kepada hal-hal yang praktis, maka dia harus diarahkan pada materi pendidikan yang bersifat ketrampilan. Sebaliknya, bila minatnya kepada masalah seni sastra atau kebudayaan, sebaiknya dia diberi kesempatan dan fasilitas yang berkaitan dengan itu, agar kelak dia benar-benar menjadi seorang sastrawan atau budayawan. Namun apabila dia berminat pada ilmu-ilmu yang lain seperti kedokteran, obatobatan, kimia dan matematika, maka seyogyanya dia diberi kesempatan untuk belajar mendalami ilmu tersebut, termasuk ilmu yang menjurus pada spesialisasi.

3. Sifat-sifat yang Harus dimiliki guru (pendidik)

Menurut Ibnu Sina, seorang guru itu seyogyanya adalah seseorang yang berakal sehat, kuat agamanya, berakhlak mulia, pandai mengambil hati anak didik, berwibawa, berkepribadian yang tangguh, berwawasan yang luas dan tidak statis, manis tutur katanya, cerdik, terpelajar, necis dan berhati suci.

Disamping itu, seorang guru haruslah orang yang mendalam ilmu pengetahuan agamanya, seorang yang shaleh dan bertaqwa kepada Allah SWT dan Rasul Nya. Seorang guru harus merasa takut melakukan perbuatan yang dilarang oleh Allah baik diketahui orang lain atau tidak. Ibnu Sina juga menganjurkan seorang pendidik hendaklah orang yang mengetahui dan mengenal betul dunia anak-anak. Itulah sebab mendidik mereka memerlukan pengalaman dan penelitian mendalam serta persiapan khusus, disamping etika atau tata krama lahiriah yang baik.

Kunci utama membenahi sistem pendidkan dan persekolahan kita ialah dengan mempersiapkan guru atau pendidik secara profesional. Ibnu Sina juga menyarankan hendaknya guru itu seorang yang cerdik dan terpelajar. Guru tidak boleh seorang yang berwawasan sempit dan statis, guru yang cerdik dan terpelajar akan disenangi dan dihormati peserta didiknya. Mereka akan memperhatikan pelajaran yang disampaikan, mereka tidak akan melanggal peraturan sekolah, meninggalkan kelas (bolos) dan lain sebagainya. Oleh karena itu seorang guru harus tulus dalam mendidikik, memperhatikan waktu belajar siswanya, selalu berpikir untuk meningkatkan kemampuan mereka dan berkeyakinan bahwa anak-anak itu 
adalah aset bangsa pada masa yang akan datang. Guru hendaknya mengetahui betul tuntunan realita hidup dimasyarakat, sehingga diharapkan mampu membekali anak didiknya dengan ilmu pengetahuan dan keterampilan yang di perlukan.

\section{Pentingnya Pendidikan Budi Pekerti (Akhlak) \\ Ibnu Sina menekankan} perkembangan anak itu diwarnai oleh nilai-nilai keagamaan yang baik, dan untuk mewujudkan hal itu, Pendidkan Agama mutlak diperlukan. Disamping itu hendaknya seorang anak itu kalau diajarkan seni sastra (syair), seyogyanya yang mengandung nilainilai yang positif dan mengarah pada pembentukan pribadi dan akhlak yang mulia.

Pendidikan budi pekerti (akhlak) ini sebenarnya merupakan tujuan utama pendidikan pada umumnya, sebab tujuan pendidikan pendidikan itu adalah membentuk orang yang berbudi pekerti luhur disamping menumbuhkan kepribadian yang kuat. Para ahli pendidikan di abad ke-20 ini telah sepakat bahwa pendidikan budi pekerti adalah tujuan pertama dan utama. Akan tetapi, hal ini tidak berarti bahwa kurang memperhatikan pendidikan jasamani, pertumbuhan akal pikiran, kepedulian sosial, kegiatan praktis atau keterampilan maupun aktivitas keilmuan lainnya. Sebab dalam pertumbuhannya peserta didik sangat memerlukan fisik jasmaniah yang sehat dan kuat, begitu juga perkembangan akal pikiran, etika, kepedulian sosial yang baik, terampil bekerja dan senang akan ilmu pengaetahuan.

Ibnu Sina memang benar-benar merindukan terlaksananya pendidikan akhlak ini, sebab menurut beliau, akhlak (budi pekerti) itu bagi kehidupan manusia adalah segala-galanya. Nilai kehidupan itu sendiri sebenarnya terletak pada akhlak tersebut. Pendidikan modern dewasa ini dengan tegas mengingatkan kepada guru bahwa pendidikan itu tidak hanya bertujuan transformasi ilmu semata, namun bertujuan terwujudnya akhlak (budi pekerti) yang mulia, seperti terbentuknya siswa yang berkepribadian baik mandiri, rajin bekerja, berlaku adil dalam segala hal, membiasakan diri berbuat baik dan bersikap hati-hati, berbicara dengan baik dan jujur, menepati janji, tulus beramal, menunaikan kewajiban dengan penuh tanggung jawab.

\section{Pentingnya memilih Teman yang Baik Akhlaknya}

Ibnu Sina berpendirian bahwa seyogyanya seorang anak itu di sekolah berkawan dengan teman yang memiliki kebiasaan yang baik dan berakhlak mulia; sebab itu biaanya meniru kebiasaan temannya. Kalau temannya nakal, dia akan ikut-ikut nakal dan sebaliknya bila anak yang baik, dia akan menjadi baik pula. Dalam mendidik anak agar menjadi anak yang berbudi pekerti yang baik, pengaruh suri tauladan, lingkungan dan kebiasaan anak itu adalah meniru temannya baik ucapan, tingkah laku maupun kebiasaan hidupnya. Sebab kecenderungan meniru merupakan pembawaan anak.

Oleh karena itu, kita harus pandaipandai memilih lingkungan tempat bergaul anak atau anak didik kita. Kita harus sering menanyakan kepadanya siapa saja teman-temannya, selalu diingatkan agar pandai memilih teman yang baik dan jangan sangan bergaul dengan anak yang tidak baik seperti yang jahat perangainya, tidak mempunyai malu, suka membangkang dan anak yang memilki kelainan jiwa. Sebab anak itu mudah dan cepat meniru dan terpengaruh teman-temannya baik 
di sekolah, di masyarakat maupun di tempat-tempat lain.

\section{Manfat Bercanda ria antar Sesama Anak}

Bercanda ria antar anak itu sangat berguna sekali untuk pengembangan dan pertumbuhan akal pikiran mereka, karena masing-masing anak akan mengemukakan apa saja yang dilihat dan didengarnya. Sering percakapan mereka terdapat cerita-cerita unik yang sangat menarik dan mendorong temannya untuk menghafal dan menceritakan kembali. Kemudian antar mereka saling bercerita dan menghafal cerita itu satu sama lain. Semuanya itu akan menumbuhkan sifat kompetitif, perasaan saling merasa hebat, saling mengenal, saling meniru. Aktivitas seperti itu sebenarnya merupakan media transformasi pendidikan budi pekerti (akhlak) pengembangan citacita dan penanaman baik di kalangan mereka.

\section{Hukuman (sanksi)}

Ibnu Sina disamping telah meletakkan dasar-dasar pendidkan budi pekerti (akhlak), beliau tidak lupa menyampaikan pandangannya tentang hukuman (sanksi) terhadap anak didik. Beliau memberikan gambaran yang komprehensif tentang cara mendidik anak dan apa saja sanksi (hukuman) yang seharusnya diberikan kepada anak itu.

Seharusnya pendidikan anak itu dimulai sedini mungkin. Sejak anak masih menyusui ibunya, hendaknya sudah dibiasakan dengan hal-hal yang baik, sehingga kehidupan anak tidak terwarnai oleh kebiasaan-kebiasaan yang tidak baik, yang sulit dihilangkan jika sudah meresap pada jiwa anak. Akan tetapi bila terpaksa harus memberikan sanksi (hukuman), maka hendaklah dijaga betul perasaan seorang anak. Pertama, jangan sekalikali anak diberi hukuman yang berat atau keras, melainkan hukuman yang lembut dan penuh kasih sayang. Hukuman hendaknya selang seling, kadang-kadang agak keras dan menakutkan. Sekali waktu, hukuman itu dalam bentuk raut wajah masam atau dengan hardikan. Dalam waktu lain hukuman dalam bentuk sanjungan atau dorongan. Dan yang paling penting sekali pujian dan motivasi lebih baik daripada cercaan. Tentu saja hal itu disesuaikan dengan kondisi tertentu.

\section{Pemikiran Pendidikan Islam menurut Ibnu Sina dan Relevansinya pada Pendidikan Islam Saat ini}

Pendidikan adalah sesuatu yang esensial bagi manusia. Dengan pendidikan manusia bisa menghadapi alam semesta demi mempertahankan hidupnya. Karena pentingnya sebuah pendidikan, Islam menempatkan pendidikan pada kedudukan yang penting dan tinggi doktrinnya. ${ }^{13}$ Semua dapat dilakukan asalkan manusia memiliki pengetahuan, mengerti tata caranya dan dapat mempraktikkannya. Jika manusia belum mengetahui, maka ia tidak dapat melakukan sesuatu di alam semesta ini.

Berbicara tentang pendidikan, cakupan yang di bahas tidak jauh dari komponen pendidikan. Komponenkomponen yang memungkinkan terjadinya proses pendidikan ada enam poin, yaitu: tujuan pendidikan, metode pendidikan peserta didik, pendidik, materi, alat dan fasilitas, serta lingkungan pendidikan. Dapat dikatakan bahwa ke-enam komponen ini sangat urgen sehingga dapat menciptakan proses belajar. Pada masa

13 Abuddin Nata, Sejarah Pendidikan Islam (Jakarta: PT. Raja Grafindo Persada, 2004), 26. 
Ibnu Sina komponen pendidikan belum administratif seperti saat ini, namun uraian pemikiran pendidikan Ibnu Sina lebih Komprehensif dibandingkan dengan era pendidikan sebelumnya. Pemikiran pendidikan yang dipaparkan oleh Ibnu Sina pada masanya, masih memiliki relevansi atau bisa dikaitkan dengan problematika pendidikan saat ini. Terkait hal tersebut dari beberapa referensi yang diperoleh penulis menjabarkannya sebagai berikut ini:

1. Tujuan Pendidikan

Menurut Ibn Sina, tujuan pendidikan harus diarahkan pada pengembangan seluruh potensi yang dimliliki seseorang ke arah perkembangannya yang sempurna, yaitu perkembangan fsik, intelektual, dan budi pekerti. ${ }^{14}$ Berdasarkan perihal tersebut tujuan pendidikan menurut Ibnu Sina dapat ditegaskan sebagai proses untuk menciptakan insan kamil yakni manusia ynag sempurna yakni terbina seluruh potensi yang dimiliki secara optimal dan menyeluruh. Sehingga pada akhirnya mampu melaksanakan fungsinya sebagai khalifah dimasyarakat.

Selain itu orientasi pendidikan menurutnya harus diarahkan pada upaya mempersiapkan seseorang agar dapat hidup di masyarakat secara bersama-sama dengan melakukan pekerjaan atau keahlian yang dipilihnya sesuai dengan bakat, kesiapan, kecenderungan, dan potensi yang dimilikinya.

Ibnu Sina nampaknya dalam memformulasikan suatu tujuan melihat kepada perkembangan potensi dan bakat yang dimiliki oleh subjek didik secara optimal dan meyuluruh,

14 Syamsul Kurniawan \& Erwin Mahrus, Jejak Pemikiran Tokoh Pendidikan.... 77

15 Maidar Darwis, Konsep Pendidikan Islam dalam Perspektif Ibnu Sina, Jurnal DIDAKTIKA Februari 2013 VOL. XIII, NO. 2 sehingga subjek didik dapat mengembangkan dirinya agar tetap eksis dalam melaksanakan fungsinya yakni sebagai khalifatullah fi ardhi dalam masyarakat dengan suatu keahlian yang dapat diandalkan. Dengan tujuan seperti ini, Ibnu Sina berusaha untuk melakukan antisipasi agar output yang dihasilkan oleh suatu lembaga pendidikan harus dapat siap kerja dengan keahlian yang dimilikinya, bukan subjek didik yang menjadi pengangguran. Jadi, tujuan yang diformulasikan oleh Ibnu Sina tersebut disamping menciptakan manusia yang paripurna (insan kamil) juga ingin mendapatkan kerja (vokasional). Dengan kata lain, Ibnu Sina dalam memformulasikan tujuan pendidikan melihat kepada dua tujuan yakni tujuan pendidikan yang bersifat universal dan tujuan pendidikan yang bersifat vokasional. ${ }^{15}$ Tujuan pendidikan ini membuat pendidikan Islam menjadi terarah dan tidak melenceng jauh dari hakikat seseorang dalam mencari ilmu.

2. Hakikat Pendidik

Banyak istilah yang digunakan untuk seorang pendidik, dalam bahasa arab seperti ustadz, mudarris, mu'allim. Pendidik adalah orang yang memikul pertanggung jawaban untuk mendidik yang meliputi orang dewasa, orang tua, guru, pemimpin masyarakat, dan pemimpin agama. ${ }^{16}$

Pendidik dalam Sistem Pendidikan Nasional adalah tenaga kependidikan yang berkualifikasi sebagai guru, dosen konselor, pamong belajar, widyaswara, tutor, instruktur, fasilitator, dan sebutan lain yang sesuai dengan kekhususannya, serta berpartisipasi dalam menyelenggarakan pendidikan. ${ }^{17}$

16 Maragustam, Filsafat Pendidikan Islam Menuju Pembentukan Karakter. (Yogyakarta: Pascasarjana Fakultas Ilmu Tarbiyah dan Keguruan UINSunan Kalijaga Yogyakarta, 2018), 206.

17 Imam Machali dan Ara Hidayat, The Hand Book of Education Management: Teori dan Praktik 
Berdasarkan beberapa pendapat di atas, seorang pendidik merupakan panutan, contoh atau figur bagi peserta didiknya. Tidak ada satupun cacat yang tampak daripadanya. Bahkan bukan hanya sifat yang perlu dijaga, cara berpakaian yang layak juga nantinya menjadi contoh bagi yang lainnya. Khususnya terhadap peserta didiknya. Dalam Islam runtutan pendidik ada empat tingkatan;

a) Allah sebagai pendidik utama, sebagaimana dalam Q. S ar-Rahman 1-4 yang artinya "Tuhan yang Maha Pemurah(1), Yang telah mengajarkan Quran(2), Dia menciptakan manusia(3), Mengajarkannya pandai berbicara(4)".

b) Rasulullah sebagai pendidik, kita ketahui bahwa Rasulullah diutus untuk menyempurnakan akhlak, yang pada saat itu masyarakat arab berada pada titik kebodohan.

c) Orang tua sebagai pendidik, contoh pendidikan dalam keluarga dilakukan oleh Luqman, dengan memberikan nasehat-nasehat tentang agama kepada anaknya. Kita ketahui pula bahwa yang bersinggungan pertama kali dengan seorang anak adalah kedua orang tuanya, terutama ibu. Maka dari itu ibu metupakan sekolah pertama untuk anak-anaknya.

d) Setiap orang adalah pendidik asalkan dia punya ilmu. Manusia adalah educandum (membutuhkan pendidikan) dan educandus (dapat mendidik orang lain). Selain itu Islam mewajibkan para pendidik untuk mendidik orang lain menghindari kemunkaran. Sesuai dengan hadis Nabi:

Pengelolaan Sekolah/Madrasah di Indonesia. (Jakarta: Prenamedia Group, 2016), 45.

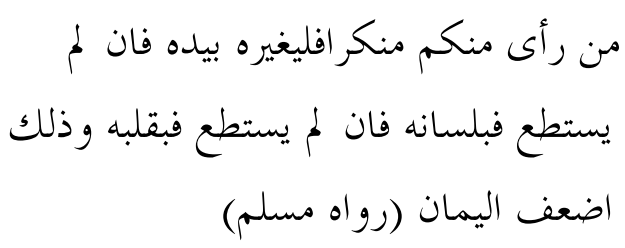

Artinya: Jika kamu melihat perbuatan munkar (keji, tindak kejahatan) maka hendaklah kamu merubah dengan tangannya, jika tidak mampu dengan lisannya, jika tidak mampu dengan hatinya dan hal yang terakhir ini adalah selemah-lemah iman. (HR. Muslim).

Dalil tersebut telah masyhur didengar dan disampaikan. Islam tidak pernah membiarkan keburukan terjadi, maka dari itu ketika melihat kemunkaran atau kekeliruan dalam melakukan suatu tidakan agar diberi teguran, ini adalah bentuk dari pendidikan dalam agama Islam.

Empat tingkatan pendidik yang telah disebutkan sebelumnya merupakan bukti, bahwa sosok atau figur seorang pendidik tidak bisa digantikan. Seseorang yang ingin mencari ilmu harus mengetahui sosok pendidiknya(gurunya).

\section{Hakikat Peserta didik}

Secara umum, peserta didik adalah setiap orang yang menerima pengaruh dari seseorang atau sekelompok orang yang menjalankan kegiatan pendidikan. ${ }^{18}$ Sedangkan menurut Undang-undang Sistem Pendidikan Nasional Nomor 20 tahun 2003 pasal 1 ayat 4 menyenebutkan Peserta didik adalah anggota masyarakat yang berusaha mengembangkan potensi diri melalui proses pembelajaran yang tersedia 
pada jalur, jenjang dan jenis pendidikan tertentu. ${ }^{19}$

Pengertian klasik menyebutkan bahwa peserta didik layaknya gelas kosong tanpa berisikan air setetespun, sehingga mereka terus menerus diisi air oleh pendidiknya. Namun teori terbaru mengatakan bahwa mereka adalah gelas yang telah terisi oleh sesuatu, dan peran pendidik adalah sebagai fasilitator. Membantu peserta didik mengembangkan pengetahuan, potensi atau kemampuan yang telah diperoleh dan dimilikinya.

Peserta didik dalam pandangan Islam ialah anggota masyarakat yang berusaha mengembangkan dirinya melalui proses pendidikan menjadi manusia yang mempunyai ilmu, iman-takwa serta berakhlak mulia sehingga mampu menjalankan fungsinya sebagai pengabdi kepada Allah dan sebagai khalifah.

Adapun etika yang harus dimiliki peserta didik dalam bab ini, salah satunya dipaparkan oleh al-Abrasyi. Etika tersebut diantaranya adalah: a) Hendaknya mensucikan hati dari hal buruk, b) Belajar ditujukan untuk memperbagus jiwa dengan kesempurnaan mendekatkan diri kepada-Nya., c) Tekun dan jauh dari penduduk dan kampung halaman, d) Tidak terburu-buru pindah ke sekolah lain, d) Menghormati gurunya, e) Tidak menyulitkan guru dengan banyak bertanya, f) Tidak membuka aib gurunya, dan lain sebagainya.

\section{Metode Pendidikan}

Pembahasan tentang metode pendidikan Islam dalam bab ini erat kaitannya agar tercapai tujuan pendidikan yang sudah di bahas sebelumnya. Penguasaan guru terhadap berbagai metode pendidikan amat diperlukan. Pasalnya tidak ada satu metode pendidikan yang tepat guna untuk semua tujuan pendidikan, semua ilmu, semua isi pelajaran, semua tahap perkembangan, kematangan dan kecerdasan peserta didik.

Oleh karena itu penggunaan metode pendidikan haruslah dipertimbangkan adanya. Dalam Islam menggunakan metode pendidikan perlu memperhatikan dasar-dasar sebagai berikut:

a) Dasar Agamis, pelaksanaan metode pendidikan harus memperhatikan nilai-nilai sumber utama Islam yakni Alquran dan Hadist.

b) Dasar Biologis, hendaknya memperhatikan kondisi biologis peserta didik, kebutuhankebutuhan jasmani dan tahap kematangan peserta didiknya.

c) Dasar Psikologis, setiap manusia memiliki kondisi psikologis yang berbeda. Hal ini bisa dipengaruhi karena emosi, minat, kematangan, kecerdasan, dan lain sebagainya.

d) Dasar Sosial, kondisi sosial juga berpengaruh terhadap metode yang digunakan. Pasalnya semua peserta didik berasal dari linkungan sosial yang berbeda pula. Menjalin interaksi yang baik adalah solusi tepat ketika menerapkan metode pendidikan.

5. Kurikulum Pendidikan

Kurikulum merupakan salah satu alat untuk mencapai tujuan pendidikan dan sekaligus sebagai pedoman dalam pelaksanaan pengajaran pada semua jenis dan

19 Undang-Undang Sistem Pendidikan Nasional Tahun 2003, 2. 
tingkat pendidikan. Banyak tokoh yang telah mendefinisikan tentang kurikulum, salah satunya oleh Abdurrahman Al-Nahlawi, yang mengartikan seluruh program pendidikan yang di dalamnya mencakup masalah-masalah metode, tujuan, tingkat pengajaran, materipelajaran setiap tahun ajaran, topik-topik pelajaran, serta aktivitas yang dilakukan setiap siswa pada setiap materi pelajaran. ${ }^{20}$

Kurikulum menurut Ahmad Tafsir (2005) menjabarkan bahwa kurikulum dapat dibagi menjadi dua macam yaitu; a) sejumlah mata pelajaran yang harus ditempuh atau dipelajari siswa disekolah atau perguruan tinggi untuk memperoleh ijazah tertentu, b) sejumlah mata pelajaran yang ditawarkan oleh suatu lembaga pendidikan atau jurusan. Selanjutnya kurikulum menurut Hilda Taba yang dikutip Ahmad Tafsir (2006), kurikulum meliputi empat aspek yaitu tujuan, isi, pola belajar mengajar dan evaluasi.

Konsep Ibnu Sina tentang kurikulum pertama dalam pendidikan dimulai dari keluarga. Pertama-tama sebaiknya anak itu belajar Al-quran, tentu saja ketika anak tersebut telah siap secara fisik dan mental untuk belajar. Pada waktu yang sama seyogyanya ia juga belajar huruf abjad, diajarkan dasardasar pendidikan agama dan belajar syair dengan dimulai dari syair-syair yang pendek agar mudah dihafal. ${ }^{21}$ Pemaparan tersebut masih relevan dengan pendidikan Islam sekarang. Orang-orang di-Barat mempercayai anak-anak dalam kandungan

20 Syamsul Kurniawan \& Erwin Mahrus, Jejak Pemikiran Tokoh Pendidikan .... 79.

21 Muhammad 'Athiyah Al-Abrasy, Pokok-Pokok Pikiran Ibnu Sina ... , 13. hendaknya diperdengarkan lagulagu klasik agar dapat merangsang kecerdasan otaknya. Begitupun dalam Islam, orang tua sang bayi diminta agar sering membaca Alqur'an yang bukan hanya sebagai penyejuk hati untuk orang tuanya, melainkan amat baik untuk masa depan sang anak pula.

Kemudian Dasar yang menjadi landasan kurikulum pendidikan Islam saat ini ditinjau dari beberapa aspek: 22

a) Dasar agama, semua itu dikembalikan kepada dua sumber utama yaitu Al-qur'an dan Assunnah Nabi SAW.

b) Dasar falsafah, yaitu memberikan arah kepada kurikulum agar mengandung suatu kebenaran, mengandung nilai makna hidup dan kehidupan, norma-norma yang muncul dari individu maupun masyarakat, atau suatu bangsa yang dipengaruhi berbagai faktor.

c) Dasar psikologis, berkaitan dengan ciri perkembangan individu peserta didik, tahap kematangannya, bakat yang dimiliki, intelektual, bahasa, emosi, dan lain sebagainya.

d) Dasar sosial, berkaitan dengan ciri-ciri masyarakat Islam yang berlaku proses pendidikan dan kebudayaan masyarakat.

Berdasarkan pemaparan diatas. Pendidikan Islam saat ini juga meletakkan Al-qur'an sebagai landasan pertama kemudian baru diikuti dasar-dasar lainnya. Hal ini membuktikan bahwa ilmu

22 Maragustam, Filsafat Pendidikan Islam Menuju Pembentukan Karakter.... 239-240. 
pengetahuan pada dasarnya berasal dari Kalamullah. Jika diurutkan kembali Kalamullah tersebut bersumber dari Allah SWT sebagai sang pemberi Ilmu.

\section{Evaluasi pengajaran}

Menurut bahasa kata evaluasi berasal dari bahasa Inggris evaluation, yang berarti penilaian atau penaksiran, bisa juga diartikan mengukur. Pengukuran tersebut bersifat kuantitatif jika berkaitan dengan angka. ${ }^{23}$

Undang-undang tentang Sistem Pendidikan Nasional tahun 2003, dalam ketentuan umum pasal 1 No 21 menyebutkan: Evaluasi pendidikan adalah kegiatan pengendalan, penjaminan, dan penetapan mutu pendidikan terhadap berbagai komponen pendidikan pada setiap jalur, jenjang dan jenis pendidikan sebagai bentuk pertanggung jawaban penyelenggaraan pertanggung jawaban pendidikan. ${ }^{24}$

Makna evaluasi dalam Al-qur'an, diantaranya: Al-hisab (mengira, menafsirkan, menghitung), Al-Hukm (putusan, vonis), Al-Qodo (putusan), Musibah (ujian), Bala (cobaan, ujian), Fitnah (ujian, cobaan, dan bencana).

Dari berbagai kata yang digunakan dalam Alquran menunjukan falsafah evaluasi dalam Islam bahwa; a) evaluasi sangat penting dalam kehidupan khususnya pendidikan, b) evaluasi bukan dimaksud untuk memperbaiki Tuhan, melainkan memperbaiki ketakwaan seseorang, c) evaluasi dimaksudkan untuk melatih kesabaran seseorang terutama

23 Maragustam, Filsafat Pendidikan Islam Menuju Pembentukan Karakter... 230-240.

${ }^{24}$ Undang-Undang Sistem Pendidikan Nasional Tahun 2003, 3 . menjalani kehidupan, d) bertujuan agar seseorang selalu istiqomah (konsisten), e) evaluasi dilakukan terus menerus, karena tidak mungkin seseorang dibiarkan mengatakan "saya beriman" tanpa diuji.

7. Hakikat lingkungan pendidikan Islam

Lingkungan menurut Kamus Besar Bahasa Indonesia adalah wilayah, kawasan yang ditinggali. Menurut Ibnu Sina anak cenderung meniru kebiasaan lingkungannya, dalam lingkungan sosial misalnya bergaul dengan teman sebayanya, anak tersebut akan meniru apa yang dilakukan temannya, bila temannya baik maka perilaku mereka akan positif, namun jika kebalikannya, maka anak tersebutakan terjerumus ke dalam perbuatan tercela. ${ }^{25}$

Lingkungan pendidikan adalah segala sesuatu yang mendukung terealisasinya pendidikan. Proses pendidikan selalu dipengaruhi oleh lingkungan yang ada disekitarnya, baik lingkungan yang menunjang maupun menghambat proses pencapaian tujuan pendidikan. Lingkungan yang mempengaruhi proses pendidikan tersebut yaitu sebagai berikut:

a. Lingkungan sosial terdiri atas; lingkungan keluarga, lingkungan sekolah atau lembaga pendidikan, dan lingkungan masyarakat.

b. Lingkungan keagamaan, yaitu nilai-nilai agama yang hidup dan berkembang disekitar lembaga pendidikan

c. Lingkungan budaya, yaitu nilai-nilai budaya yang hidup

25 Muhammad 'Athiyah Al-Abrasy, PokokPokok Pikiran Ibnu Sina tentang ... hlm 33. 
dan berkembang disekitar lembaga pendidikan

d. Lingkungan alam, baik keadaan iklim maupun geografisnya.

Sebelum mengenal lingkungan luar, manusia terlebih dahulu mengenal lingkungan dalam keluarganya. Maka dari itu lingkungan keluarga yang baik akan membentuk karakter kuat bagi anak. Mengnjak usia sekolah, barulah mereka menganal kehidupan di lingkungan sekolahnya. Disana mereka belajar bermacam-macam ilmu pengetahuan yang belum diperolehnya selama berada di lingkungan keluarga. Kemudian puncaknya adalah belajar di Lingkungan masyarakat, bertemu dengan berbagai macam sifat dan karakter manusia.

Berjalannya waktu manusia tumbuh dan mengalami perubahan, baik perubahan fisik dan cara berfikir mereka khsunya dalam menyelesaikan permasalahan. Lingkungan keagamaan, budaya dan alam amat mempengaruhi terhadap tumbuh kembang manusia itu sendiri.

\section{SIMPULAN}

Pokok pemikiran pendidikan menurut Ibnu Sina sudah kompleks di zamannya. Karena dunia pendidikan dan ilmu pengetahuan itu bersifat dinamis dan selalu berubah, kontribusi pemikiran pendidikannya masih dapat direlevansikan di beberapa point, namun kurang cocok ketika diterapkan keseluruhan pada pendidikan saat ini. Pokok pemikiran pendidikan Ibnu sina membahas beberapa hal urgen dalam dunia pendidikan yaitu, tentang tujuan pendidikan, kurikulum, hakikat pendidik, peserta didik, lingkungan belajar. Kesemuanya dibahas secara umum, bersifat sederhana dan tidak tersistem seperti saat ini. Jika dikaitkan dengan pendidikan modern, pemikiran pendidikan beliau dapat menambah khazanah keilmuan dan menjadi tinjauan filosofis bagi pemikir pendidikan Islam sekarang.

\section{REFERENSI}

Al-Ahwani, Ahmad Fuad Filsafat Islam, cet. VIII. (Jakarta: Pustaka Firdaus, 1997)

Al-Abrasy, Muhammad 'Athiyah. PokokPokok Pikiran Ibnu Sina tentang Pendidikan. (Isa al-Babi wa syirkah, 1994)

Alwizar, "Pemikiran Pendidikan Ibnu Sina: an-Nida'." Jurnal Pemikiran Islam, Vol. 40, No.1 Januari-Juni 2015.

Asf, Jasmani Syaiful Mustofa. Supervisi Pendidikan: Terobosan Baru dalam Peningkatan Kinerja Pengawas Sekolah dan Guru. (Jogjakarta: Ar-Ruzz Media, 2013)

Assegaf, Abdurrahman. Aliran Pemikiran Pendidikan Islam Hadhradh Keilmuan Tokoh Klasik Sampai Modern. (Jakarta: Raja Grafindo, 2013)

Aziz, Safrudin, Pemikiran Pendidikan Islam, (Yogyakarta: Kalimedia, 2015)

Darwis, Maidar. "Konsep Pendidikan Islam dalam Perspektif Ibnu Sina," Jurnal Ilmiah DIDAKTIKA Vol. XIII, No. 2, Februari 2013

Kurniawan, Syamsul \& Erwin Mahrus. Jejak Pemikiran Tokoh Islam. (Yogyakarta: Ar-Ruzz Media, 2011)

Machali, Imam dan Ara Hidayat. The Hand Book of Education Management: Teori dan Praktik 
Pengeelolaan Sekolah/Madrasah

di Indonesia. (Jakarta:

Prenamedia Group, 2016)

Maragustam. Filsafat Pendidikan Islam

Menuju Pembentukan Karakter.

(Yogyakarta: Pascasarjana

Fakultas Ilmu Tarbiyah dan

Keguruan UIN Sunan Kalijaga, 2018)

Muhammad Nasher, al-Fikr al-Tarbawi al-'Arabi al-Islami: al-juz'u alTsani min Qira'at fi al-Fikr alTarbawi (Kuwait:Wukalah alMathba'at, 1977)

Nata, Abuddin. Sejarah Pendidika Islam. (Jakarta: PT. Raja Grafindo Persada, 2004)

Suwito dan Fauzan. Sejarah Pemikiran Para Tokoh Pendidikan. (Bandung: Angkasa, 2003)

Undang-Undang Sistem Pendidikan Nasional Tahun 2003 